\title{
DAYA SERAP ARANG AKTIF TONGKOL JAGUNG SEBAGAI MEDIA FILTER DALAM MENURUNKAN KADAR BESI (Fe) PADA AIR
}

\author{
Suwantiningsih ${ }^{1}$, Khambali ${ }^{2}$, Narwati $^{3 *}$ \\ 1,2,3 Department of Environmental Health, Poltekkes Kemenkes Surabaya.
}

\section{Artikel Info :}

Received 2 Agustu 2020

Accepted 20 Agustus 2020

Available online 24 Agustus

2020

Editor: Mei Ahyanti

Key word :

Corn cobs, Activated carbon, Iron, Filter

Kata Kunci :

Tongkol jagung, Karbon aktif, Besi, Filter

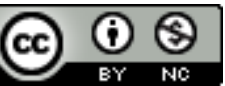

Ruwa Jurai: Jurnal

Kesehatan Lingkungan is licensed under a Creative Commons

Attribution-NonCommercial 4.0

International License.

\begin{abstract}
A bstract
Corn cobs are a solid waste that has not been maximally utilized and can pollute the environment. Corn cobs can be used as activated charcoal because they contain cellulose (41\%) and hemicellulose (36\%). The research objective was to determine the ability of corncob activated charcoal to reduce water iron (Fe) content in water. True Experiment research with pretest-posttest design with control group design with 6 repetitions. The mass variation of corn cobs activated charcoal in the filter media used was 2,920 gr, 4,380 gr, and 5,840 gr. The number of samples of the artificial iron solution used for each repetition of each of the variations in the mass of the adsorbent was 7 litres so that the total required was 168 litres. The data obtained were analyzed using One Way Anova. The results showed the levels of Fe after treatment in the mass variation of activated charcoal cob $2920 \mathrm{gr}$ was $2.55 \mathrm{mg} / \mathrm{L}$, at 4,380 gr mass was 1.67 $\mathrm{mg} / \mathrm{L}$, and in the mass $5.840 \mathrm{gr}$ was $0.64 \mathrm{mg} / \mathrm{L}$. The highest reduction efficiency in iron content was in the mass of $5,840 \mathrm{gr}$ which was able to reduce Fe levels up to $85.70 \%$.

This study proves that activated corn cobs can be used as an absorbent to reduce levels of iron (Fe) in water.
\end{abstract}

Tongkol jagung merupakan salah satu limbah padat yang belum maksimal dimanfaatkan dan dapat mencemari lingkungan. Tongkol jagung dapat dimanfaatkan sebagai arang aktif karena mengandung selulosa (41\%) dan hemiselulosa (36\%). Tujuan penelitian untuk mengetahui kemampuan arang aktif tongkol jagung dalam menurunkan kadar besi air ( $F e$ ) pada air. Penelitian True Experiment dengan desain pretest-posttest with control group design dengan 6 kali pengulangan. Variasi massa arang aktif tongkol jagung pada media filter yang digunakan adalah $2.920 \mathrm{gr}, 4.380 \mathrm{gr}$, dan $5.840 \mathrm{gr}$. Jumlah sampel larutan besi buatan yang digunakan untuk setiap kali pengulangan pada masing-masing variasi massa adsorben sebanyak 7 liter, sehingga total dibutuhan sebanyak 168 liter. Data yang diperoleh dianalisis menggunakan One Way Anova. Hasil penelitian munjukkan kadar Fe setelah perlakuan pada variasi massa adsorben arang aktif tongkol $2.920 \mathrm{gr}$ sebesar $2,55 \mathrm{mg} / \mathrm{L}$, pada massa $4.380 \mathrm{gr}$ sebesar 1,67 $\mathrm{mg} / \mathrm{L}$, dan pada massa $5.840 \mathrm{gr}$ sebesar $0,64 \mathrm{mg} / \mathrm{L}$. Efisiensi penurunan kadar besi tertinggi pada massa 5.840 gr yang mampu menurunkan kadar Fe hingga 85,70\%. Penelitian ini membuktikan bahwa arang aktif tongkol jagung dapat digunakan sebagai absorben untuk menurunkan kadar besi (Fe) pada air.

\footnotetext{
* Corresponding author : Narwati

Jl. Pucang Jajar Tengah No.56, Kertajaya, Kec. Gubeng, Kota Surabaya, Jawa Timur 60282.

Email: narwatisuprapto@gmail.com
}

\section{PENDAHULUAN}

Air merupakan salah satu kebutuhan dasar bagi manusia. Namun, masih banyak masyarakat yang menggunakan air sumur untuk keperluan sehari-hari tanpa memikirkan kualitas air yang digunakan. Salah satu sumber air bersih yang masih banyak digunakan adalah air tanah dangkal yang diperoleh melalui sumur gali (sumur dangkal). Keberadaan besi dalam air bersifat terlarut dalam air, dampak besi pada air 
menjadi merah kekuning-kuningan, menimbulkan bau amis, dan membentuk lapisan seperti minyak, bila konsentrasi besi larutnya > 1,0 mg/L (Joko, 2010). Keberadaan kadar besi (Fe) pada air yang tinggi dapat dilakukan proses pengolahan agar air yang dihasilkan memenuhi persyaratan sebagai air bersih sesuai Permenkes No 32 Tahun 2017.

Pengolahan sederhana yang dapat dilakukan yaitu, menggunakan proses pengolahan adsorpsi pada media filter dengan karbon aktif atau arang aktif. Arang aktif dapat diperoleh dari material yang mengandung karbon misalnya tulang, kayu lunak, sekam, tongkol jagung, tempurung kelapa, sabut kelapa, ampas penggilingan tebu, ampas pembuatan kertas, serbuk gergaji, kayu keras, batubara dan sebagainya (Kusumaningrum dan Indah Nurhayati, 2016).

Tongkol jagung merupakan salah satu limbah yang dapat digunakan sebagai bahan baku absorben kadar besi ( $F e$ ) di air. Tongkol jagung mengandung selulosa (41\%) dan hemiselulosa (36\%) yang dapat digunakan sebagai bahan baku pembuatan karbon aktif (Agustina dan Fitrina, 2018). Besarnya jumlah persentase selulosa yang di dalam tongkol jagung, sehingga dapat digunakan sebagai alternatif bahan baku arang aktif sebagai adsorben yang digunakan pada proses adsorpsi (Martina, Rum dan Widodo, 2016).

Produksi jagung di Indonesia pada tahun 2019 mencapai 19.612 .435 ton sehingga limbah tongkol jagung yang dihasilkan juga sangat besar. Dari data Badan Pusat Statistik tahun 2019, diperkirakan limbah tongkol jagung yang dihasilkan di Indonesia sekitar 5,7 juta ton/tahun. Kabupaten Tuban merupakan salah satu sentra produksi jagung terbesar di Jawa Timur. Jumlah produksi jagung yang dihasilkan dari industri jagung pipil di Kecamatan Grabagan Kabupaten Tuban mencapai 434,94 ton per tahun dengan limbah tongkol jagung yang dihasilkan 73,38 ton.

Penelitian Yevitasari (2013) yang menggunakan variasi ketebalan arang aktif $60 \mathrm{~cm}, 70 \mathrm{~cm}$, dan $80 \mathrm{~cm}$ pada air sumur dengan kadar $\mathrm{Fe}$ sebesar $2,15 \mathrm{mg} / \mathrm{l}$, mendapatkan penurunan kadar $\mathrm{Fe}$ sebesar 92,09\%, menjadi $0,17 \mathrm{mg} / \mathrm{L}$. Efektifitas penurunan kadar $\mathrm{Fe}$ tertinggi pada ketebalan $80 \mathrm{~cm}$.
Penggunaan tongkol jagung sebagai bahan baku arang aktif memiliki beberapa kelebihan, antar lain memiliki kandungan karbon yang lebih tinggi dibandingkan kadar abu, mudah didapat dan melimpah terutama pasca panen, harganya murah, mudah dalam pembuatan dan aplikasinya, serta aman bagi lingkungan karena terbuat dari bahan organik. Penelitian bertujuan untuk menguji kemampuan arang aktif dari tongkol jagung yang digunakan sebagai media filter pada variasi massa adsorben untuk menurunkan kadar besi ( $F e$ ) pada air.

\section{METODE}

Jenis penelitian adalah true-experiment menggunakan rancangan pretest-posttest with control group design dengan enam kali pengulangan. Penelitian dilakukan di Laboratorium Politeknik Kesehatan Surabaya pada Februari hingga Maret 2020.

\section{Pembuatan Arang Aktif}

Bahan baku tongkol jagung kering diperoleh dari limbah industri jagung pipil di Kecamatan Grabagan Kabupaten Tuban. Langkah pertama adalah melakukan proses karbonisasi dengan cara pembakaran. Arang yang diperoleh selanjutnya dilakukan penghalusan dan diayak menggunakan saringan ukuran 100 mesh, sehingga diperoleh ukuran butiran carbon yang homogen.

Proses aktivasi dilakukan dengan cara perendaman menggunakan larutan $\mathrm{HCl} 5 \%$ selama 24 jam. Meniriskan HCL dan menetralkan asam dengan melakukan pencucian menggunakan aquades. Selanjutnya arang aktif basah dikeringkan dalam oven pada suhu $100^{\circ} \mathrm{C}$ selama 1 jam, dan dimasukkan ke dalam desikator selama 15 menit.

\section{Pembuatan Tabung Media Filter}

Tabung media filter menggunakan pipa PVC 4 inch dengan ketinggi $130 \mathrm{~cm}$. Membuat lubang dan pada dop salah satu tutup pipa PVC dengan diameter $3 / 4$ inchi, dilengkapi sock drat luar dan sock drat dalam. Selanjutnya dilakukan pemasangan dop bawah dengan dilengkapi filter dan kran.

Memasang dop atas dilengkapi dengan saringan (srainer). Memasukkan media filter dengan susunan ijuk $10 \mathrm{~cm}$, arang aktif tongkol 
jagung, ijuk $10 \mathrm{~cm}$, dan kerikil dengan ketebalan $10 \mathrm{~cm}$. Ketebalan arang aktif tongkol jagung mengikuti variasi massa adsorben, yaitu $2.920 \mathrm{gr}$
$(40 \mathrm{~cm}), 4.380 \mathrm{gr}(60 \mathrm{~cm})$, dan $5.840 \mathrm{gr}(80 \mathrm{~cm})$. Tabung filter terdapat pada Gambar 1.

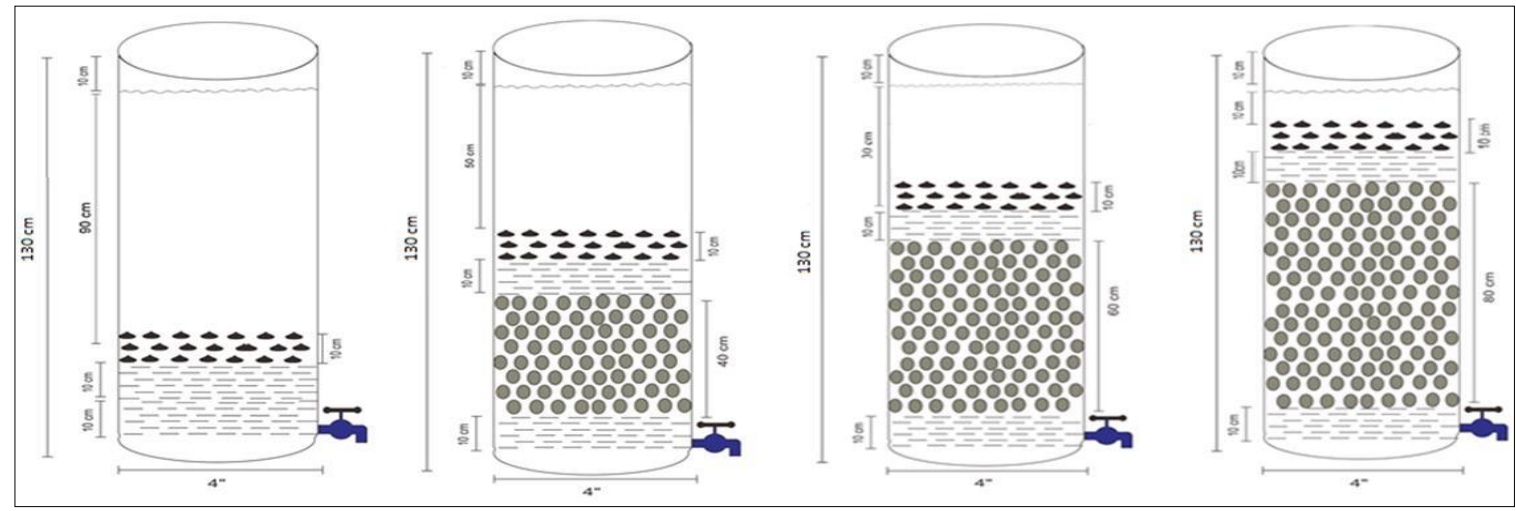

Gambar 1. Desain Media Filter Arang Aktif Tongkol Jagung (a) kontrol, (b) variasi massa adsorben $2.920 \mathrm{gr}(40 \mathrm{~cm}),(\mathrm{c}) 4.380 \mathrm{gr}(60 \mathrm{~cm})$, (d) $5.840 \mathrm{gr}(80 \mathrm{~cm})$

\section{Pembuatan larutan besi}

Pembuatan larutan besi buatan yang mengandung besi dengan perencanaan dosis 4,50 mg/L. Pada setiap perlakuan dibutuhkan $7000 \mathrm{~mL}$ larutan besi (Fe), sehingga volume larutan besi yang dibutuhkan untuk 3 kelompok perlakuan dan 1 kelompok kontrol adalah sebanyak $168.000 \mathrm{~mL}$, atau 168 Liter.

Pembuatan larutan besi dilakukan dengan cara melarutkan serbuk besi sebanyak $756 \mathrm{gr}$, dengan mengikuti persamaan :

$\frac{m 1}{v 1}=\frac{m 2}{v 2}$

$\mathrm{m} 1$ = massa serbuk awal

$\mathrm{m} 2=$ massa serbuk yang diinginkan $\quad(\mathrm{mg})$

$\mathrm{v} 1=$ volume larutan awal $\quad(\mathrm{mL})$

$\mathrm{v} 2=$ volume yang diinginkan $\quad(\mathrm{mL})$

Serbuk besi sebanyak 756 mg dilarutkan dengan 168 Liter aquades, dan selanjutnya digunakan sebagai sampel air baku dalam penelitian. Sebelum digunakan, dilakukan pemeriksaan kadar besi pada air baku menggunakan dengan metode SSA (Spektrofotometri Serapan Atom).

\section{Perlakuan dan analisis}

Pada setiap perlakuan, dialirkan sebanyak 7 liter air baku dengan waktu kontak selama 6 menit. Pengambilan sampel dilakukan dengan cara membuka kran pembuka dan dimasukkan dalam botol sampel. Selanjutnya sampel diuji untuk mengetahui kadar besi dengan metode SSA (Spektrofotometri Serapan Atom).

Data yang diukur adalah kadar besi (Fe) sebelum dan sesudah perlakuan, serta persentase penurunan yang diinterpretasikan melalui grafik. Data yang diperoleh dianalisis menggunakan uji One Way Anova.

\section{HASIL}

1. Karakteristik arang aktif tongkol jagung

Pemeriksaan kadar air dan kadar abu yang dilakukan pada arang aktif tongkol jagung untuk mengetahui gambaran karakteristiknya. Hasil pemeriksaan mendapatkan bahwa kadar air arang aktif tongkol jagung sebesar 5,49\%. Nilai kadar air ini sudah memenuhi baku mutu SNI 06-3730-1995, yaitu kadar airn tidak melebihi $15 \%$.

Hasil pemeriksaan kadar abu arang aktif tongkol jagung sebesar 9,84\%, juga memenuhi persyaratan SNI 06-3730-1995 karena hasilnya tidak melebihi $10 \%$. Hasil pemeriksaan kadar air dan kadar debu ditampilkan pada Tabel 1.

Tabel 1. Kadar Air dan Kadar Abu Arang Aktif Tongkol Jagung

\begin{tabular}{ll}
\hline Parameter & Hasil \\
\hline Kadar Air & $5,49 \%$ \\
Kadar Abu & $9,84 \%$ \\
\hline
\end{tabular}

2. Pemeriksaan Kadar Besi (Fe) Setelah Perlakuan 
Hasil penelitian mendapatkan bahwa ratarata kadar besi $(\mathrm{Fe})$ terendah setelah perlakuan diperoleh dari variasi massa $5.840 \mathrm{gr}$, yaitu sebesar 0,64 mg/L. Sedangkan kadar besi $(\mathrm{Fe})^{\prime}$ tertinggi diperoleh dari variasi massa 2.920gr, yaitu sebesar 2,55mg/L. Hasil pemeriksaan kadar besi $(\mathrm{Fe})$ sebelum dan sesudah perlakuan pada Table 2.

Tabel 2. Hasil Pengukuran Kadar Besi (Fe) Berdasarkan Variasi Perlakuan

\begin{tabular}{lllll}
\hline Kelompok & Pretest & $\begin{array}{l}\text { Rata-Rata } \\
\text { Posttest } \\
(\mathrm{mg} / \mathrm{L})\end{array}$ & $\begin{array}{l}\text { Tingkat } \\
\text { Penurunan } \\
(\mathrm{mg} / \mathrm{L})\end{array}$ & $\begin{array}{l}\text { Persentase } \\
\text { Penurunan }\end{array}$ \\
\hline Kontrol & 4,50 & 4,42 & 0,08 & $1,78 \%$ \\
$2.920 \mathrm{gr}$ & 4,50 & 2,55 & 1,95 & $43,33 \%$ \\
$4.380 \mathrm{gr}$ & 4,50 & 1,67 & 2,83 & $62,89 \%$ \\
$5.840 \mathrm{gr}$ & 4,50 & 0,64 & 3,86 & $85,78 \%$ \\
\hline
\end{tabular}

3. Penurunan Kadar Besi (Fe) Berdasarkan Variasi Perlakuan

Rata-rata penurunan dan persentase penurunan kadar Besi ( $\mathrm{Fe}$ ) ditampilkan pada Gambar 2. Terlihat bahwa tingkat penurunan tertinggi terjadi pada perlakuan dengan menggunakan variasi massa $5.840 \mathrm{gr}$, yaitu sebesar 85,78\%. Sedangkan terendah pada variasi massa $2.920 \mathrm{gr}$, sebesar $43,33 \%$. Hasil ini menunjukkan bahwa semakin tebal penggunaan media karbon aktif pada waktu kontak yang sama, maka akan semakin tinggi pula tingka penurunan kadar Besi (Fe).

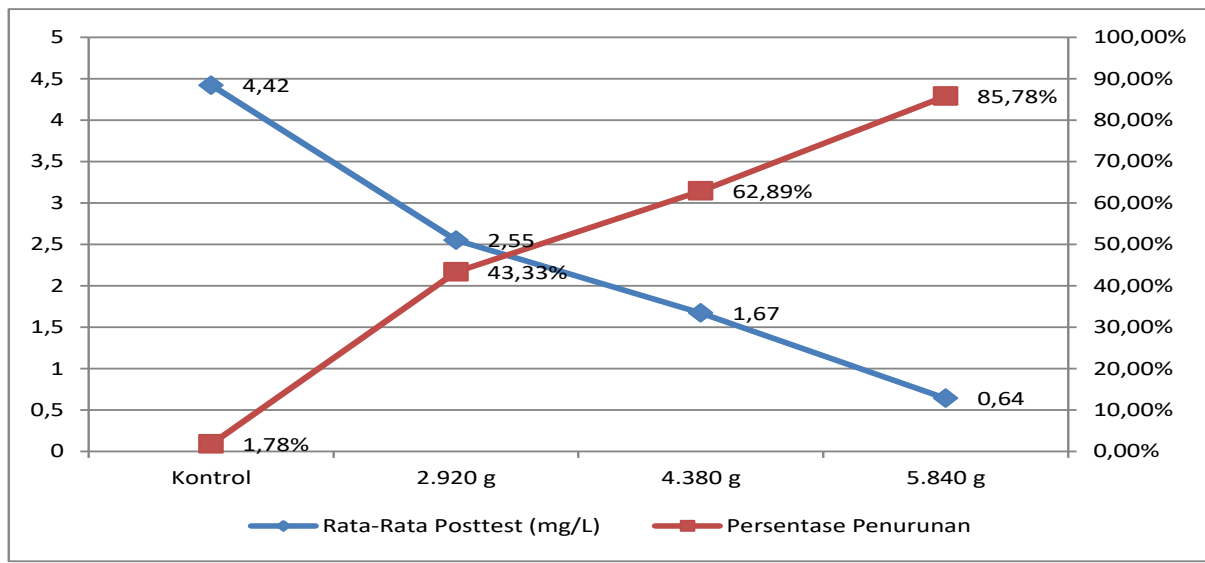

Gambar 2. Penurunan Kadar Besi (Fe) Berdasarkan Variasi Perlakuan

4. Kemampuan Arang Aktif Dalam Menurunkan Kadar Besi (Fe)

Dilakukan analisis statistik menggunakan uji One Way Anova $(\alpha=0,05)$ untuk membuktikan perbedaan hasil perlakuan. Hasil analisis statistik membuktikan adanya perbedaan Kadar Besi ( $F e$ ) yang nyata pada variasi perlakuan $(p$-value $=0,000)$. Analisis statistik pada Tabel 3.
Kemudian dilakukan uji Least Square Difference ( $L S D$ ) untuk mengetahui perbedaan antar kelompok perlakuan. Hasil analisis statistik menunjukkan adanya perbedaan kadar besi $(\mathrm{Fe})$ pada setiap pasangan perlakuan ( $p$-value $=0,000$ ). Hasil analisis juga menunjukkan bahwa perlakuan dengan massa adsorben $5.840 \mathrm{gr}$ memberikan rata-rata perbedaan yang tertinggi. Hasil analisis pada Tabel 4. 
Tabel 3. Hasil Analisis One Way Anova

\begin{tabular}{lllll}
\hline & $\begin{array}{l}\text { Sum of } \\
\text { Squares }\end{array}$ & $\begin{array}{l}\text { Mean } \\
\text { Square }\end{array}$ & F & Sig. \\
\hline Between Groups & 10,891 & 5,445 & 6250,944 & 0,000 \\
Within Groups & 0,013 & 0,001 & & \\
Total & 10,904 & & & \\
\hline
\end{tabular}

\section{PEMBAHASAN}

\section{Arang Aktif Tongkol Jagung}

Tongkol jagung merupakan limbah pertanian dengan volume berlimpah pasca pemanenan. Selain berpotensi untuk mengatasi polutan seperti logam berat, tongkol jagung juga dapat ditingkatkan nilai ekonominya menjadi arang aktif. Sehingga mengurangi potensi pencemaran lingkungan yang dapat mengakibatkan bau tidak sedap (Yuningsih, Mulyadi dan Kurnia, 2016).

Pada proses pembuatan arang aktif dilakukan uji kualitas yang dibandingkan dengan standar SNI 06-3730-1995 untuk menguji kadar air dan kadar abu. Kadar air yang dihasilkan dari arang aktif tongkol jagung yaitu 5,49\% sehingga memenuhi SNI 06-3730-1995 untuk arang aktif yang berbentuk serbuk karena kurang dari $15 \%$.

Kadar abu yang dihasilkan arang aktif tongkol jagung sebesar 9,84\% sehingga juga memenuhi persyaratan SNI 06-3730-1995 berbentuk serbuk yaitu lebih kecil dari 10\%. Kadar abu sangat mempengaruhi kualitas dari arang aktif, kadar abu yang berlebihan dapat mengakibatkan penyumbatan pori arang aktif sehingga luas permukaan dari arang aktif dapat berkurang (Meisrilestari, Khomaini \& Wijayanti,
2013). Pada umumnya, kandungan bahan mentah yang berbeda akan menghasilkan karbon aktif yang berbeda sifat fisika dan kimianya. Faktor yang berpengaruh pada kualitas arang aktif yang dihasilkan juga tergantung dari proses pembuatan karbon aktif.

Pada Tabel 2 terlihat bahwa jumlah kadar besi (Fe) sesudah perlakuan semakin rendah dengan bertambahnya massa adsorben arang aktif tongkol jagung. Hal ini membuktikan bahwa daya adsorpsi arang aktif dipengaruhi oleh massa adsorben yang digunakan, yaitu dengan bertambahnya ketebalan, maka semakin luas permukaan pori-pori yang dapat menyerap kadar besi $(\mathrm{Fe})$, sehingga semakin banyak pula kadar besi ( $\mathrm{Fe}$ ) yang terjerap.

Hal ini juga sesuai pada penelitian Antonia Nunung Rahayu \& Adhitiyawarman, (2014) tentang pemanfaatan limbah tongkol jagung sebagai adsorben besi pada air tanah, yang mengatakan bahwa bertambahnya massa adsorben mengakibatkan jumlah pertikel, luas permukaan dan ruang kosong pada pori-pori yang melimpah sehingga dapat terjadi penyerapan kadar besi ( $\mathrm{Fe}$ ) secara maksimal.

Tabel 4. Hasil Uji LSD Penurunan Kadar Besi (Fe)

\begin{tabular}{lllll}
\hline $\begin{array}{l}\text { (I) Massa adsorben } \\
\text { arang aktif }\end{array}$ & $\begin{array}{l}\text { (J) Massa } \\
\text { adsorben } \\
\text { arang aktif }\end{array}$ & $\begin{array}{l}\text { Mean } \\
\text { Difference }\end{array}$ & Std. Error & Sig. \\
\hline \multirow{2}{*}{$2.920 \mathrm{gr}$} & $4.380 \mathrm{~g}$ & 0,877 & 0,017 & 0,000 \\
& $5.840 \mathrm{~g}$ & 1,903 & 0,017 & 0,000 \\
$4.380 \mathrm{gr}$ & $2.920 \mathrm{~g}$ & $-0,877$ & 0,017 & 0,000 \\
& $5.840 \mathrm{~g}$ & 1,027 & 0,017 & 0,000 \\
$5.840 \mathrm{gr}$ & $2.920 \mathrm{~g}$ & $-1,903$ & 0,017 & 0,000 \\
& $4.380 \mathrm{~g}$ & $-1,027$ & 0,017 & 0,000 \\
\hline
\end{tabular}




\section{Penurunan Kadar Besi (Fe) Berdasarkan Variasi Perlakuan}

Massa adsorben merupakan salah satu faktor yang mempengaruhi proses adsorbsi. Massa adsorben yang digunakan dapat memberikan pengaruh terhadap proses adsorpsi, dimana semakin banyak adsorben yang digunakan semakin banyak pula adsorbat yang dapat terserap. Akan tetapi, terlalu banyak massa adsorben yang diberikan juga tidak efektif untuk melakukan proses penyerapan.

Pada Gambar 2, penurunan kadar besi ( $F e$ ) mengalami peningkatan dengan bertambahnya massa adsorben. Arang aktif yang mempunyai tingkat penurunan kadar besi $(\mathrm{Fe})$ paling rendah yaitu pada kelompok $2.920 \mathrm{gr}$, sebesar $43,33 \%$. Sedangkan penurunan tertinggi pada terjadi pada perlakuan dengan menggunakan variasi massa $5.840 \mathrm{gr}$, yaitu sebesar $85,78 \%$. Pada kelompok kontrol yang tidak dikontakkan dengan media arang aktif, juga terjadi penurunan kadar Besi $(\mathrm{Fe})$ sebesar 1,78\%, diduga dari proses aerasi.

Pada proses filtrasi, air dialirkan melalui media yang diisi arang aktif tongkol jagung. Saat air melewati media, maka tongkol jagung akan menyerap kadar besi (Fe) yang besar penyerapannya dipengaruhi oleh luas permukaan arang aktif. Semakin luas permukaan arang aktif, maka semakin tinggi tingkat penyerapan yang terjadi. Hal ini sejalan dengan penelitian Nuuruningrum, (2017) bahwa semakin banyak arang aktif yang digunakan semakin besar luas permukaan arang aktif yang menyerap besi (Fe) dalam air karena jarak yang harus ditempuh oleh air juga semakin panjang dalam proses adsorbsi yang dilakukan.

\section{Efektivitas Arang Aktif Tongkol Jagung}

Berdasarkan hasil analisis statistik dengan menggunakan uji One Way Anova, diperoleh tingkat signifikansi sebesar $p$-value $=0,000$. Hasil ini menunjukkan perbedaan yang nyata pada variasi perlakuan, yaitu $2.920 \mathrm{gr}, 4.380 \mathrm{gr}$, dan $5.840 \mathrm{gr}$. Sedangkan hasil uji LSD menujukkan perbedaan kadar besi (Fe) pada setiap kelompok perlakuan (Tabel 4).

Dari hasil yang diperoleh kelompok massa adsorben $5.840 \mathrm{gr}$ merupakan kelompok yang paling tinggi memberikan efek terhadap penurunan kadar besi (Fe). Pada kelompok perlakuan $2.920 \mathrm{gr}$ dan $4.380 \mathrm{gr}$, nilai kadar besi (Fe) setelah perlakuan masih melebihi nilai maksimum yang diperbolehkan. Sedangkan pada pada perlakuan dengan massa adsorben $5.840 \mathrm{gr}$, nilai kadar besi ( $\mathrm{Fe}$ ) telah memenuhi standar air bersih menurut Permenkes RI No. 32 Tahun 2017, yaitu sebesar 1mg/L.

Pada penelitian ini, massa adsorben yang paling efektif untuk menurunkan kadar besi ( $F e$ ) adalah $5.840 \mathrm{gr}$ dengan penurunan sebesar $3,86 \mathrm{mg} / \mathrm{l}$. Terjadinya perbedaan penurunan kadar besi ( $\mathrm{Fe}$ ) akibat adanya perbedaan massa adsorben arang aktif yang digunakan pada media filter. Sejalan dengan penelitian Mantong, Argo \& Susilo, (2018) bahwa semakin banyak arang aktif yang digunakan, maka nilai adsorpsinya terhadap ion logam semakin tinggi dan sebanding dengan bertambahnya jumlah partikel dan luas permukaan arang aktif.

\section{Efesiensi Penurunan Kadar Besi (Fe) Pada Variasi Perlakuan}

Pada kelompok perlakuan dengan berbagai variasi massa adsorben arang aktif tongkol jagung, didapatkan hasil yang berbeda pada kadar besi $(F e)$ sebelum dan sesudah perlakuan, sehingga efesiensi yang dihasilkan juga berbeda pada setiap perlakuan.

Keberhasilan suatu adsorben dalam proses adsorbsi dapat diketahui dari efisiensi yang dihasilkan, semakin besar persentasi penurunan maka proses adsorpsi semakin maksimal. Berdasarkan hasil penelitian ini, maka efisiensi terendah penurunan kadar besi ( $\mathrm{Fe}$ ) adalah menggunakan masa absorben 2.920gr (penurunan 43,33\%). Sedangkan tertinggi menggunakan masa absorben $5.840 \mathrm{gr}$ (penurunan $85,78 \%$ ).

Pada kelompok perlakuan, persentase penurunan kadar besi ( $\mathrm{Fe}$ ) akan semakin meningkat dengan semakin bertambahnya massa adsorben arang aktif tongkol jagung. Dari hasil efisiensi membuktikan bahwa semakin banyak adsorben yang digunakan maka efisiensi yang dimiliki akan semakin meningkat. Menurut Ningsih dan Said, (2016), dengan semakin bertambahnya berat adsorben maka tingkat efisiensi juga semakin meningkat dan mencapai kesetimbangan karena kerapatan sel arang aktif dalam larutan sehingga menghasilkan interaksi yang cukup efektif antara arang aktif dengan 
logam Fe. Semakin banyak zat penyerap maka semakin banyak aktif arang yang teraktivasi yang akan bereaksi.

\section{SIMPULAN}

Penelitian ini membuktikan bahwa limbah tongkol jagung dapat digunakan sebagai bahan baku pembutan arang aktif untuk media penurunan kadar besi (Fe) dalam air. Penggunaan arang aktif tongkol jagung sebanyak $5.840 \mathrm{gr}$, mampu menurunkan kadar besi ( $\mathrm{Fe}$ ) sebesar $85,87 \%$.

Perlu penelitian lebih lanjut untuk mengetahui variabel-variabel lain yang belum diteliti, antara lain pengaruh variasi waktu kontak, variasi ukuran granular karbon aktif, variasi metode pembuatan karbon aktif, dan efektifitas karbon aktif limbah tongkol jagung pada parameter kimia air lainnya.

\section{DAFTAR PUSTAKA}

Agustina, S. dan Fitrina, A. 2018. Proses Peningkatan Luas Permukaan Karbon Aktif Tongkol Jagung. Seminar rekayasa teknologi semrestek, e-ISSN : 2, hlm: 440-446.

Antonia Nunung Rahayu dan Adhitiyawarman. 2014. Pemanfaatan Tongkol Jagung Sebagai Adsorben Besi Pada Air Tanah. Jurnal Kimia dan Kemasan, 3(3), hlm: 7-13.

Joko, T . 2010. Unit Produksi dalam Sistem Penyediaan Air Minum. Yogyakarta: Graha IImu.

Kusumaningrum, W. dan Indah Nurhayati. 2016. Penggunaan Karbon Aktif Dari Ampas Tebu Sebagai Media Adsorbsi Untuk Menurunkan Kadar Fe (Besi) dan Mn (Mangan) Pada Air Sumur Gali di desa Gelam Candi. Jurnal Teknik
Waktu, 14(01), hlm: 1-7.

Mantong, J. O., Argo, B. D. dan Susilo, B. 2018. Pembuatan Arang Aktif Dari Limbah Tongkol Jagung Sebagai Adsorben Pada Limbah Cair Tahu. Jurnal Keteknikan Pertanian Tropis dan Biosistem, 6(2), hlm: 100-106.

Martina, D., Hastuti, R. dan Didik Setiyo Widodo. 2016. Peran Adsorben Selulosa Tongkol Jagung (Zea mays) dengan Polivinil Alkohol (PVA) untuk Penyerapan Ion Logam Timbal $\left(\mathrm{Pb}^{2+}\right)$. Jurnal Kimia Sains dan Aplikasi, 19(3), hlm: 77-82.

Meisrilestari, Y., Khomaini, R. dan Wijayanti, H. 2013. Pembuatan Arang Aktif dari Cangkang Kelapa Sawit dengan Aktivasi Secara Fisika, Kimia dan Fisika dan Kimia. Jurnal Konversi, 2(1), hlm: 45-50.

Ningsih, D. A. dan Said, I. 2016. Adsorpsi Logam Timbal ( $\mathrm{Pb}$ ) Dari Larutannya Dengan Menggunakan Adsorben Dari Tongkol Jagung. Jurnal Akademika Kimia, 5(2), hlm: 55-60.

Nuuruningrum, I. 2017. Pemanfaatan Limbah Tongkol Jagung (Zea mays Linn) Sebagai Arang Aktif dalam Menurunkan Kadar Besi (Fe) Air Sumur Gali Warga di Kelurahan Jati Utomo Kecamatan Binjai Utara Tahun 2017. Skripsi Fakultas Kesehatan Masyarakat, Universitas Sumatera Utara.

Yevitasari, D. C. 2013. Keefektifan Ketebalan Karbon Aktif Sebagai Media Filter Terhadap Penurunan Kadar Besi (Fe) Air Sumur. Artikel Publikasi Ilmiah, Program Studi Kesehatan Masyarakat, Universitas Muhammadiyah Surakarta.

Yuningsih, L. M., Mulyadi, D. dan Kurnia, A. J. 2016. Pengaruh Aktivasi Arang Aktif dari Tongkol Jagung dan Tempurung Kelapa Terhadap Luas Permukaan dan Daya Jerap Iodin. Jurnal Kimia VALENSI, 2(1), hlm: 30-34 